\title{
Green Economy Investment Program as a Way to Improve the Ecology of the Country's Mining Regions
}

\author{
Tatiana Shpilkina ${ }^{1}$, Margarita Zhidkova ${ }^{1}$, and Nadezhda Filimonova ${ }^{2}$ \\ ${ }^{1}$ Moscow Automobile and Road Construction State Technical University (MADI), 125319 \\ Leningradsky prospect 64, Moscow, Russia \\ ${ }^{2}$ Russian New University, 105005 Radio st., 22, Moscow, Russia
}

\begin{abstract}
The article outlines the problems of the "green" economy, notes the importance of environmental issues for sustainable socio-economic development and national security of Russia. The authors note the need for the formation in the Russian Federation of an effective policy for the sustainable use of natural resources jointly by the leading countries of the world. The role of the national project "Ecology" and the direction "Clean Air" is shown, measures are proposed to solve environmental problems. The areas of coverage of emissions of industrial gases into the atmosphere are highlighted on the example of oil and gas companies; the ways to reduce them using a number of methods for each area of coverage separately are shown. The importance of decarbonization is substantiated, not only as a mean to solve environmental and climatic problems, but also as a way to ensure the differentiation of mineral goods and competitiveness on a global scale.
\end{abstract}

\section{Introduction}

Modern trends in the development of the economy dictate the new rules for mining industry development. This is due to many reasons, the main of which are environmental issues and climate change. Serious problems arose during the pandemic, when "... the world community faced the unforeseen problem, which, for the most part, had a negative impact on all spheres of public life, caused by coronavirus infection" [1]. The pandemic has changed the lives of many people, brought a lot of problems, but at the same time, like any crisis, it revealed painful problems. It was during this pandemic that politicians, scientists and researchers turned their attention to the environment and green economy.

Environmental issues, problems of environmental pollution, clean air are increasingly being raised on the agenda of governments in many countries of the world. Extraction of minerals, production goods by many industries creates harmful waste and leads to environmental pollution. In addition, over the past 20 years, Russia has begun to actively use large volumes of plastic and other harmful substances in the manufacture of products, which, in general, can lead to an environmental disaster. "The transition from traditional model of economic development to the "green economy" is a global trend that determines the 
sustainability not only of individual national economies, but of the entire planet as a whole, and the promotion of the "green economy" is the main path of development" [2].

Therefore, the allocation by the Government of the Russian Federation of the National Project "Ecology" did not raise questions from the public, since this is one of the problem areas in many regions of the country. The national project is designed for the period 20182024. The "Clean Air" project is also an important National Project. It lists 12 industrial cities in Russia, such as Bratsk, Krasnoyarsk, Lipetsk, Magnitogorsk, Mednogorsk, Nizhny Tagil, Novokuznetsk, Norilsk, Omsk, Chelyabinsk, Cherepovets and Chita, in which comprehensive measures are planned to reduce air pollution.

According to this project, a significant role is played by the creation of control and monitoring system for pollutant emissions from large industrial enterprises, as well as the transition of facilities of this category to the best available technologies. It is planned to spend 480.5 billion rubles for these purposes in 6 years, including a little more than 100 billion rubles of state budget funds [3]

\section{Materials and Methods}

The President of the Russian Federation, in his Address to Parliament in April 2021, announced the key directions of the country's development, and paid attention to environmental problems and their solution. According to experts, Russia pays a high price for environmental pollution, which is expressed in the premature mortality of about 100 thousand people every year and socio-economic damage in the amount of about 5\% of GDP, which is an order of magnitude higher than the current damage from disasters of a climatic origin. Therefore, "the President's proposal is not to be limited to the reduction of harmful emissions by $20 \%$ in the indicated 12 largest industrial cities of Russia established by the federal project "Clean Air" by 2024, but also to expand such quotas to all cities where air quality problems are acute. Experts have calculated that there are more than 40 such cities" [4].

Despite the significant funds allocated for the project, this may not be enough to improve the quality of life of Russians in the foreseeable future, unless a safe level of concentration of harmful substances in the air is established as a target criterion. Only under this condition, the volume of emission reduction can be an indicator of a real positive change in the environmental situation, and become the basis for state support of business projects for the environmental modernization of enterprises. "The problem of environmental safety is becoming relevant in the modern period due to imperfect environmental control and limited financial resources of the state and mining enterprises for environmental protection measures" [5].

The main efforts in the modernization of enterprises, as well as in the elimination of accumulated environmental damage, the risks and scale of damage from which exceed the socio-economic losses from the current level of environmental pollution, remain the prerogative of the owners of enterprises. They are the ones who have to pay for damage to environment. Increasing the responsibility of such enterprises will ensure the environmental safety of the population and the surrounding area throughout the entire life cycle of the facility. Technologically, this will happen within the framework of a circular economy, in which the waste of an enterprise is involved in economic circulation, becoming the subject of labor of another process. To its stimulation in 2021, it is envisaged to launch a mechanism for extended liability of manufacturers and importers for the disposal of goods and packaging [4].

The environmental costs of companies should not be viewed as a mere burden on producers. The introduction of green technologies is becoming part of the production process, and green investments are becoming part of the financing of work to create the final "green" 
product. It is necessary to integrate elements of a green economy into the work of companies of different sizes and industries. Without taking these elements into account, it becomes impossible either to develop a company strategy, or to build relationships with suppliers and customers of products, or to carry out operational activities [6].

If we look at the financial side of the implementation of the presented approach, then a significant addition to environmental payments that go to the federal budget could be an increase in insurance payments for owners of environmentally hazardous enterprises, whose activities are regulated by Federal Law No. 225 dated July 27, 2010 "On Compulsory Civil Liability Insurance for owner of a hazardous facility for causing harm as a result of an accident at a hazardous facility" (as amended on 18.12.2018 N 473-FZ) [7].

Emergencies that occurred in Norilsk in 2020, Usolye-Sibirskoye and some other regions of Russia made it possible to conclude that the existing liability insurance mechanism clearly needs to be improved. The specific of the civil liability of enterprises operating with the sources of high danger is that they are always responsible for the harm caused by such a source, except for cases where it is proved that the harm was caused as a result of force majeure circumstances (when it is impossible to either foresee or prevent the action of such circumstances).

Another step towards the implementation of the green agenda could be the consideration of the issue of introducing a market mechanism for environmental regulation - by analogy with the internal carbon regulation mechanism being created in the country and already actively functioning abroad, primarily in Europe. It provides for accounting and circulation of carbon units and aims to reduce greenhouse gas emissions. This mechanism was developed in the United States in the mid-1970s in relation to the emission of harmful pollutants, and became an important element of the success in the radical reduction of dangerous air pollution with sulfur oxide and lead in the late 1980s. Such a mechanism could become an incentive to reduce harmful emissions and waste, and their accumulation. In addition, it would successfully complement the mechanism of internal carbon regulation that is emerging in Russia, associated with the implementation of climate policy objectives.

Based on the President's Address, it can be stated that the issues of ecology and the development of the "green" economy are priorities. Moreover, it is necessary to deal with them for sustainable socio-economic development and national security of Russia, and to determine actions to comprehensively solve the problem of global warming and its consequences. It is also necessary to take care of preserving the potential of Russian ecosystems, first of all, forest wetlands, which annually lose millions of hectares due to forest and peat fires, and also suffer from the consequences of global warming, especially in the northern regions of the Russian Federation. This requires a qualitatively different, effective forest policy, and a policy of sustainable nature management. For this reason, broad and effective international cooperation in this area is proposed (Fig. 1) [4].

Reducing greenhouse gas (GHG) emissions is becoming an important task not only for governments of different countries, but also for entrepreneurs. Decarbonization today is not only a means to address environmental and climate challenges, but also a way to ensure product differentiation and global competitiveness. 


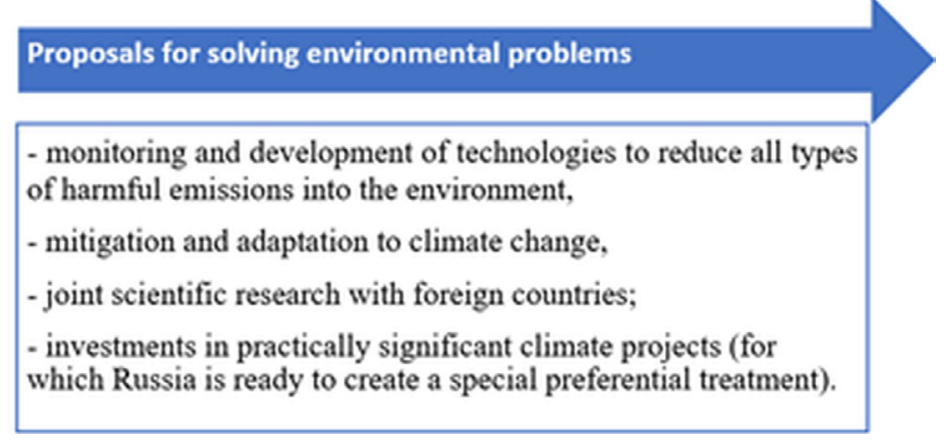

Fig. 1. The main proposals for solving environmental problems in the world economy.

Not only regulators and governments, but also investors around the world are beginning to view climate risks as investment risks and are reluctant to finance high-emission sectors such as ultra-high-viscosity Arctic oil and bituminous oil. "For example, BlackRock (one of the world's largest investment companies), World Bank, JPMorgan, the Swedish pension fund Sjunde, the Norwegian Government Pension Fund Global, the banks Goldman Sachs, Deutsche Bank, BNP Paribas, Socidtd Gendrale, European Investment Bank, Allianz Insurance Company and others. The majority of institutional and private investors around the world, who collectively control over $\$ 14$ trillion in assets, have signed up to divestiture commitments in the fossil fuel sector" [8].

At the same time, the financial sector (lenders and investors) is starting to play an increasingly active role in promoting decarbonization. Various types of climate finance are used for this purpose: directed lending, green bonds, loan guarantee programs, weather index insurance, feed-in tariffs, tax breaks, national development banks, disclosure policies, and national climate funds. Financial institutions today pay special attention to various reporting mechanisms (GRI, TCFD, SASB), using them to assess and disclose their climate risks. Financial regulators are also reinforcing this trend by constantly increasing their requirements for banks and investors to disclose climate information [8].

\section{Results and Discussion}

It is international practice to classify emissions into three scopes. The first area is direct emissions from the production activities of companies in the industry [8-10]. In the oil and gas sector, this group includes greenhouse gas emissions during the production, transportation and processing of oil and natural gas, flaring of associated petroleum gas (APG), as well as in the process of operation of its own sources of energy and heat supply for production facilities and processes of the company [11-13]. In the second scope, it is customary to include indirect emissions of greenhouse gases associated with the operation of energy and heat sources from which the oil and gas company acquires them for its own needs (Table 1). 
Table 1. Coverage of greenhouse gas emissions.

\begin{tabular}{|c|c|c|}
\hline $\begin{array}{c}\text { Scope of coverage 1 } \\
\text { (Direct emissions) }\end{array}$ & $\begin{array}{c}\text { Scope of coverage 2 } \\
\text { (Indirect emissions) }\end{array}$ & $\begin{array}{c}\text { Scope of coverage 3 } \\
\text { (Other indirect } \\
\text { emissions) }\end{array}$ \\
\hline $\begin{array}{c}\text { 1. Installation for oil } \\
\text { refining }\end{array}$ & 1. Purchase of heat & $\begin{array}{c}\text { 1. Petroleum products } \\
\text { (own) }\end{array}$ \\
\hline 2. Tankers. & $\begin{array}{c}\text { 2. Purchase of } \\
\text { electricity }\end{array}$ & $\begin{array}{c}\text { 2. Petroleum products } \\
\text { (resale) }\end{array}$ \\
\hline 3. APG flaring & & $\begin{array}{c}\text { 3. Oil and gas sold to } \\
\text { other refineries. }\end{array}$ \\
\hline
\end{tabular}

If we restrict ourselves to only direct and indirect spheres of coverage of emissions, then the role of the oil and gas sector in global anthropogenic emissions is not so great, this industry accounts for only $12 \%$ of total emissions. This is more than emissions from manufacturing industries (9\%), but less than emissions from agriculture. Most of the emissions fall on the fuel and energy complex (74\%), the least on waste, only $3 \%$ (Fig. 2).

The main problem in the oil and gas sector is related to the third scope of emissions, which includes emissions associated with the use of products of oil and gas companies, that is, the combustion of oil and gas fuels.

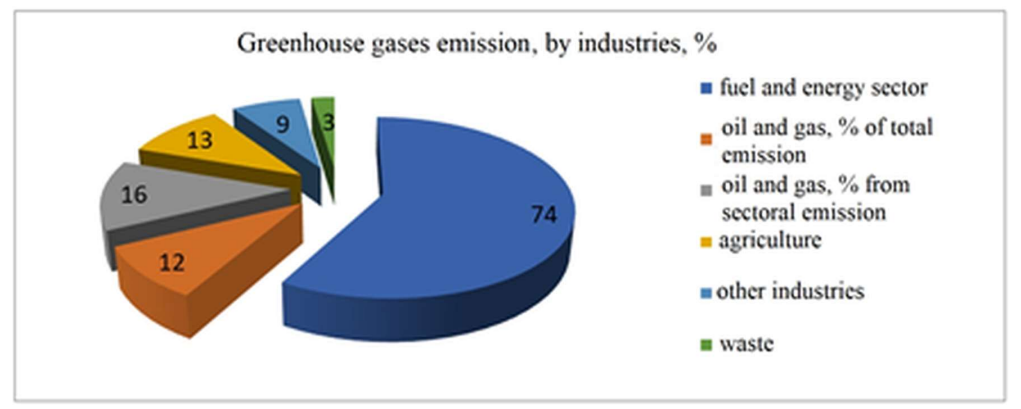

Fig. 2. Emissions of greenhouse gases in the world by economic sectors in $2017, \%$.

Another very important specific feature of the oil and gas sector is a high proportion of methane emissions (up to $45 \%$ of its total greenhouse gas emissions) in the process of oil and gas production and transportation, while it should be borne in mind that methane causes a greater greenhouse effect than carbon dioxide [8].

The Paris Agreement and the recommendations of the Task Force on Climate-related Financial Disclosures are pushing companies to articulate their long-term decarbonization strategies and disclose their efforts in this area. This trend is constantly strengthening, more and more companies from all over the world are joining it: if in 2016 only 5 oil and gas companies publicly formulated commitments to reduce greenhouse gas emissions, by 2019 there were already 15. In addition, in August 2020, the Chinese corporation PetroChina announced its intention to reduce greenhouse gas emissions to zero net by 2050 and start investing in RES (renewable energy sources) and pilot hydrogen projects. PetroChina has set the following plan for itself. Achieving zero emissions by 2050 in line with the developed low-carbon and green development strategy, and Shell also expects to achieve zero emissions by 2050 (Scope 1 and 2), reducing carbon intensity by $30 \%$ by 2035 and by $65 \%$ by 2050 compared to 2016 (Scope 3). Other oil and gas companies have a similar program of action [8]. 
To reduce emissions and improve the environmental situation in terms of coverage, it is proposed to use the following methods (Table 2).

Table 2. Methods for reducing greenhouse gas emissions by scope.

\begin{tabular}{|c|c|c|}
\hline Scope of coverage 1 & Scope of coverage 2 & Scope of coverage 3 \\
\hline $\begin{array}{l}\text { 1. Operating methods: } \\
\text { - increasing the operational } \\
\text { efficiency of enterprises; } \\
\text { - energy efficient production } \\
\text { equipment; } \\
\text { - recycling and reuse and disposal } \\
\text { of secondary energy resources; } \\
\text { - working with suppliers of } \\
\text { equipment and services to reduce } \\
\text { their carbon footprint. }\end{array}$ & $\begin{array}{l}\text { 1. Operating methods } \\
\text { - energy efficiency of } \\
\text { buildings; } \\
\text { - working with } \\
\text { suppliers of electricity } \\
\text { and heat to reduce } \\
\text { their carbon raw } \\
\text { materials. }\end{array}$ & $\begin{array}{l}\text { 1. Methods of corporate } \\
\text { strategy: } \\
\text { - optimization of the asset } \\
\text { portfolio; } \\
\text { - trade in carbon permits; } \\
\text { - carbon credits; } \\
\text { - reduction of greenhouse gas } \\
\text { emissions through } \\
\text { investments in land use based } \\
\text { on regenerative technologies. }\end{array}$ \\
\hline $\begin{array}{l}\text { 2. Effective monetization of } \\
\text { methane and APG: } \\
\text { - reduction of APG flaring; } \\
\text { - reduction of methane leaks; } \\
\text { - use of vapor recovery units and } \\
\text { reduction of methane leaks from } \\
\text { large reservoirs; } \\
\text { - tracking uncontrolled emissions } \\
\text { into the atmosphere from non- } \\
\text { working wells. }\end{array}$ & $\begin{array}{l}\text { 2. Conversion of } \\
\text { enterprises to low- } \\
\text { carbon energy } \\
\text { sources: } \\
\text { - RES, excluding } \\
\text { biomass; } \\
\text { - use of energy storage } \\
\text { devices; } \\
\text { - use of hydrogen for } \\
\text { own needs. }\end{array}$ & $\begin{array}{l}\text { 2. Capture, storage and use of } \\
\mathrm{CO} 2 \text {; direct capture of } \mathrm{CO} 2 \\
\text { from the air: } \\
\text { - capture, storage and use of } \\
\text { carbon; } \\
\text { - direct capture of } \mathrm{CO} 2 \text { from } \\
\text { the air; } \\
\text { - injection of } \mathrm{CO} 2 \text { under } \\
\text { pressure into the formation; } \\
\text { - bioenergy using carbon } \\
\text { capture and storage } \\
\text { technology. }\end{array}$ \\
\hline & & $\begin{array}{l}\text { 3. Production, sale and use of } \\
\text { hydrogen: } \\
\text { - production, transportation } \\
\text { and sale of hydrogen ("green" } \\
\text { and "blue" hydrogen). }\end{array}$ \\
\hline
\end{tabular}

\section{Conclusion}

Summing up the results of the study, let us highlight the main results and provisions.

1. According to the authors, modern trends in economic development dictate more and more new rules for conducting work in the mining industry. This is due to many reasons, the main of which are environmental issues and climate change. The problems of the "green" economy are priority not only for Russia, but also for the world. Moreover, it is necessary to deal with them for sustainable socio-economic development and national security of Russia. This requires a qualitatively effective forest policy, and a policy of sustainable environmental management of the Russian Federation with the leading countries of the world.

2. Topical issues for Russia are the implementation of the national project "Ecology" for the period 2018-2024, and the national project "Clean Air". According to this project, a significant role is played by the creation of a control and monitoring system for pollutant emissions from large industrial enterprises, as well as the transition of facilities of this category to the best available technologies. It is planned to spend 480.5 billion rubles for these purposes in 6 years, including a little more than 100 billion rubles of state budget funds. 3. All emissions in international practice are usually classified into three areas of coverage.

The first scope of coverage is direct emissions from the production activities of companies in the industry. The second scope includes indirect greenhouse gas emissions associated with the operation of energy and heat sources from which the oil and gas company acquires them 
for its own needs. The third scope of coverage includes emissions associated with the use of products of oil and gas companies, that is, combustion of oil and gas fuels.

4. A number of appropriate methods have been developed to reduce emissions and greenhouse gases into the atmosphere by 20150 .

In Scope 1, these are operational methods, including increasing the operational efficiency of enterprises, energy efficient production equipment, etc., as well as effective monetization of methane and APG.

In Scope 2 - operational methods that involve energy efficiency of buildings, working with electricity and heat suppliers to reduce their carbon raw materials, etc., transferring enterprises to low-carbon energy sources.

In Scope 3 - corporate strategy methods, including portfolio optimization, carbon credits, etc.; capture, storage and use of $\mathrm{CO}_{2}$ and direct capture of $\mathrm{CO}_{2}$ from the air; production, sale and use of hydrogen.

So, the environmental safety of production should be accompanied by the development of new nature saving technologies, the decrease in the volume of emissions into the atmosphere and the development of a "green" economy, using decarbonization, not only as a means to solve environmental and climatic problems, but also as a way to ensure global competitiveness.

\section{References}

1. A.A. Gordievskaya, T.A. Shpilkina, Impact of COVID-19 on the development of a green economy in 2020 (OmSU, Omsk, 2020)

2. I.A. Baydina, Green economy - the economy of tomorrow (OmSU, Omsk, 2017)

3. RBC Information Agency. URL: https://www.rbc.ru/

4. B. Porfir'ev, Expert 18-19(1205), 19-21 (2021)

5. V. Frolova, O. Dolina, T. Shpilkina, E3S Web Conf. 41, 04027 (2018)

6. E.V. Malysh, "Green" rental investment in regional development (UFU, Ekaterinburg, 2018)

7. Consultant Plus Server. URL: http://www.consultant.ru/

8. T. Mitrova, Expert 16(1203), 34-41 (2021)

9. O. Kalenov, S. Kukushkin, E3S Web Conf. 174, 02024 (2020)

10. S. Kukushkin, O. Kalenov, R. Kamanina, O. Kosareva, E3S Web Conf. 174, 04014 (2020)

11. V. Frolova, O. Dolina, T. Shpilkina, E3S Web Conf. 105, 01054 (2019)

12. E.Y. Dotsenko, N.P. Ezdina, A.S. Khasanova, M.I. Khasanov, E3S Web Conf. 247, 01068 (2021)

13. E. Dotsenko, N. Ezdina, S. Mudrova, E3S Web Conf. 105, 02008 (2019) 